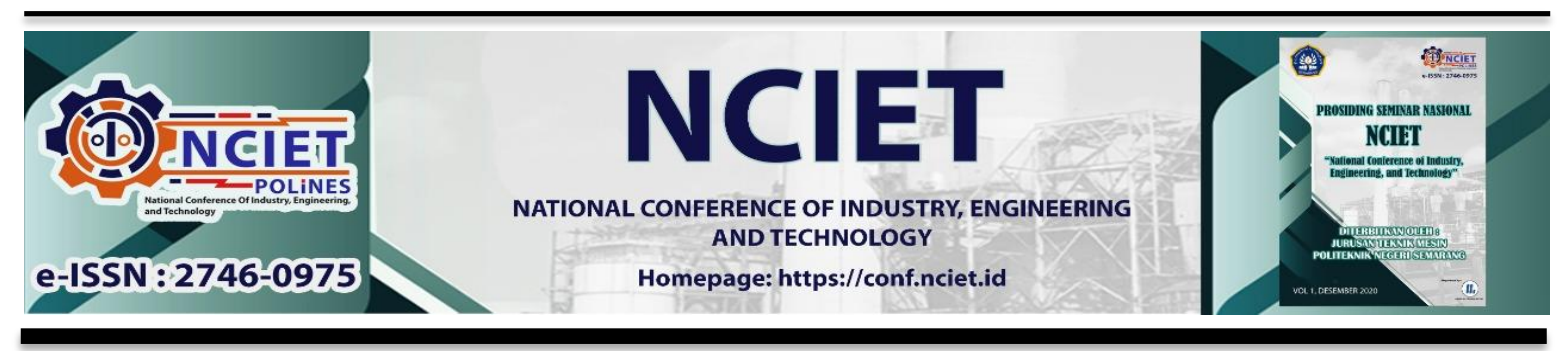

Prosiding Seminar Nasional NCIET Vol.1 (2020) B67-B78

$1^{\text {st }}$ National Conference of Industry, Engineering and Technology 2020,

Semarang, Indonesia.

\title{
OPTIMASI TEKANAN VAKUM MAIN CONDENSER MENGGUNAKAN ANALISIS EXERGY DI PLTP KAMOJANG
}

\author{
Arief Wicaksono $^{1}$, Widjonarko ${ }^{2}$, Bayu Rudiyanto ${ }^{*}$ \\ ${ }^{1}$ Jurusan Teknik, Politeknik Negeri Jember \\ Jl. Mastrip, Kotak Pos 164, Jember, 68121 \\ ${ }^{2}$ Jurusan Teknik Elektro, Universitas Jember, \\ Jl. Kalimantan 37, Jember, 68121 \\ *E-mail: bayu_rudianto@polije.ac.id
}

\begin{abstract}
Abstrak
Optimasi tekanan vakum main condenser pada PLTP Kamojang menggunakan analisis exergy dimana analisis ini dilakukan berdasarkan hukum termodinamika kedua. Analisis exergy memberikan informasi mengenai efisiensi exergy dan irreversibilitas pada tiap komponen. Laju exergy dihitung pada tiap state dan masing-masing komponen pembangkit meliputi steam receiving header, separator, demister, turbin, main condenser, inter condenser, after condenser dan cooling tower. Hasil analisis exergy menunjukkan laju exergy dari sumur produksi sebesar $95327 \mathrm{~kW}$ yang digunakan untuk membangkitkan listrik sebesar $52882 \mathrm{~kW}$ dengan nilai efisiensi exergy sistem sebesar 55,47\% dan irreversibilitas tertinggi terjadi pada turbin yaitu senilai 12874 $\mathrm{kW}$. Optimasi dilakukan dengan variasi tekanan vakum pada main condenser untuk mengetahui tekanan vakum yang optimal dengan menghasilkan efisiensi exergy dan daya output tertinggi. Hasil optimasi menunjukkan semakin rendah tekanan vakum main condenser akan menyebabkan peningkatan efisiensi exergy dan daya output. Tekanan vakum optimal yang diperoleh sebesar 0,1 bar yang menghasilkan efisiensi exergy dan daya output tertinggi masing-masing sebesar 57,42\% dan $54738 \mathrm{~kW}$ dengan irreversibilitas terendah sebesar $32751,07 \mathrm{~kW}$.
\end{abstract}

Kata Kunci: exergy; efisiensi; irreversibilitas; main condenser; optimasi.

\section{PENDAHULUAN}

Seiring dengan pertumbuhan penduduk dan ekonomi di Indonesia menyebabkan kebutuhan energi juga semakin meningkat baik di sektor bahan bakar maupun ketenagalistrikan. Berdasarkan skenario BaU (Business as Usual) dalam Outlook Energi Indonesia (2019), pertumbuhan permintaan tenaga listrik diproyeksikan mencapai sekitar 576,2 TWh pada tahun 2025 dan 2.214 TWh pada tahun 2050 dengan laju permintaan tenaga listrik rata-rata sebesar 7\% per tahun selama periode 2018-2050 (DEN, 2019).

Indonesia memiliki cadangan panas bumi terbesar di dunia, yaitu sebesar 28.910 MW atau sekitar $40 \%$ dari energi total panas bumi dunia dan tersebar di 342 lokasi (Darma et al, 
2010). Saat ini, potensi energi panas bumi di Indonesia yang termanfaatkan sebagai pembangkit listrik baru sebesar 1.948,30 MW yang terdapat pada 13 Wilayah Kerja Panas Bumi (WKP) (KESDM, 2019). Salah satu pembangkit listrik tenaga panas bumi yaitu PLTP Kamojang Unit 1,2 dan 3 dengan kapasita terbangkit 142 MW.

Unit pembangkit dilengkapi dengan komponen yang disebut dengan Steam Receiving Header untuk mencegah fluktuasi aliran uap yang akan berdampak langsung pada unit pembangkit. Steam Receiving Header merupakan bejana bertekanan yang terhubung dengan vent valve system untuk membuang kelebihan uap serta mengontrol tekanan dan aliran uap. Kemudian uap menuju separator untuk memisahkan uap dengan kotoran dan air yang terikut. Untuk meningkatkan fraksi uap dan membersihkan mist atau bintik air yang masih terikut, uap kemudian menuju ke demister. Setelah dari demister, uap kering bertekanan tinggi masuk ke turbin dan menghasilkan daya mekanik poros turbin untuk menghasilkan listrik. sebagian kecil uap keluar demister digunakan untuk steam ejector dan gas removal system. Skema diagram PLTP Kamojang ditunjukkan pada Gambar 1 berikut.

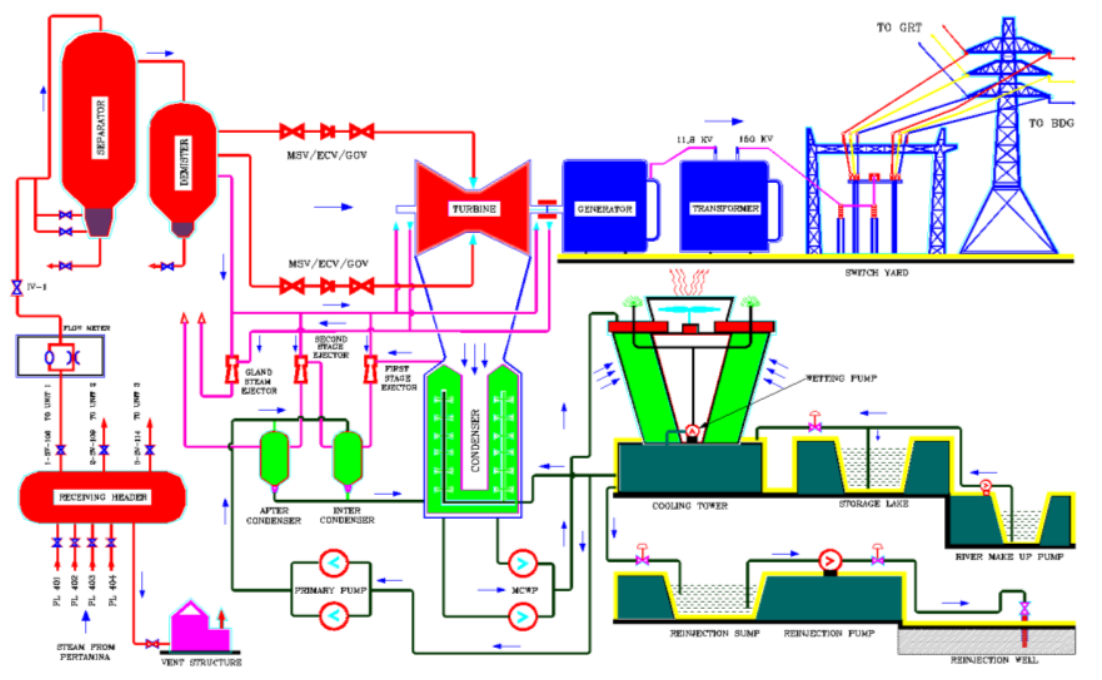

Gambar 1. Skema PLTP Kamojang

Pembangkit listrik tenaga panas bumi Kamojang dalam pengoperasiannya menggunakan beberapa komponen penting salah satunya adalah main condenser yang berfungsi untuk mengubah fasa uap menjadi cair dengan metode kontak langsung dengan air pendingin. Selama beroperasi, terdapat kerugian-kerugian (losses) yang dialami main condenser sehingga perlu adanya evaluasi kinerjanya. Upaya yang dapat dilakukan adalah dengan mengevaluasi dan mengoptimalkan dengan pendekatan termodinamika menggunakan analisis exergy. 
Metode analisis exergy dilakukan menggunakan kesetimbangan exergy berdasarkan model fisik dari sistem termal dengan kombinasi parameter energi dan entropi. Jenis analisis ini cocok untuk menentukan energi yang tidak terpakai dan hilang untuk mendapatkan gambaran yang lebih jelas mengenai konversi energi (Rudiyanto, 2017). Hasil analisis dengan menggunakan metode ini akan memberikan gambaran yang sesungguhnya tentang besarnya kerugian dari suatu sistem, apa penyebabnya, dan dimana lokasinya sehingga dapat digunakan sebagai acuan untuk melakukan peningkatan kinerja sistem secara keseluruhan atau hanya pada komponen-komponennya (Dincer, 2002).

Penelitian ini difokuskan pada PLTP Kamojang Unit 3 dan membahas tentang analisis exergy pada sistem PLTP Kamojang untuk mengevaluasi kinerja sistem pembangkit saat proses konversi energi. Tujuan dari penelitian ini untuk menganalisis exergy dan irreversibilitas PLTP Kamojang yang akan menentukan efisiensi, letak kerugian dan penyebab kerugian exergy tersebut. Data yang telah didapatkan kemudian dihitung dan disimulasikan menggunakan software Engineering Equation Solver (EES). Hasil yang diperoleh digunakan untuk mengopimasi sistem yang dapat meningkatkan efisiensi exerg yang diperoleh digunakan untuk mengopimasi sistem yang dapat meningkatkan efisiensi exergy. Optimasi dilakukan pada tekanan vakum pada main condenser berdasarkan analisis yang telah dilakukan. Hal ini untuk mengetahui besarnya tekanan vakum main condenser yang optimal untuk menghasilkan efisiensi exergy sistem dan daya output yang maksimal.

\section{METODE PENELITIAN}

Metode yang digunakan dalam penelitian ini adalah analisis dengan melakukan simulasi dan variasi tekanan vakum main condenser menggunakan analisis exergy. Pengumpulan data dengan cara penyelidikan objek penelitian melalui dokumen tertulis yang diarsipkan pada $\log$ sheet harian PLTP Kamojang untuk menghimpun data meliputi laju aliran massa ( $\dot{\mathrm{m}})$, tekanan $(\mathrm{P})$, dan temperature $(\mathrm{T})$ pada tiap komponen, temperatur lingkungan, dan daya pembangkit. Analisis data dilakukan untuk mengetahui laju exergy pada tiap komponen dengan perangkat lunak Engineering Equation Solver serta optimasi pada tekanan vakum main condenser untuk menghasilkan nilai efisiensi exergy dan daya output yang maksiaml. 

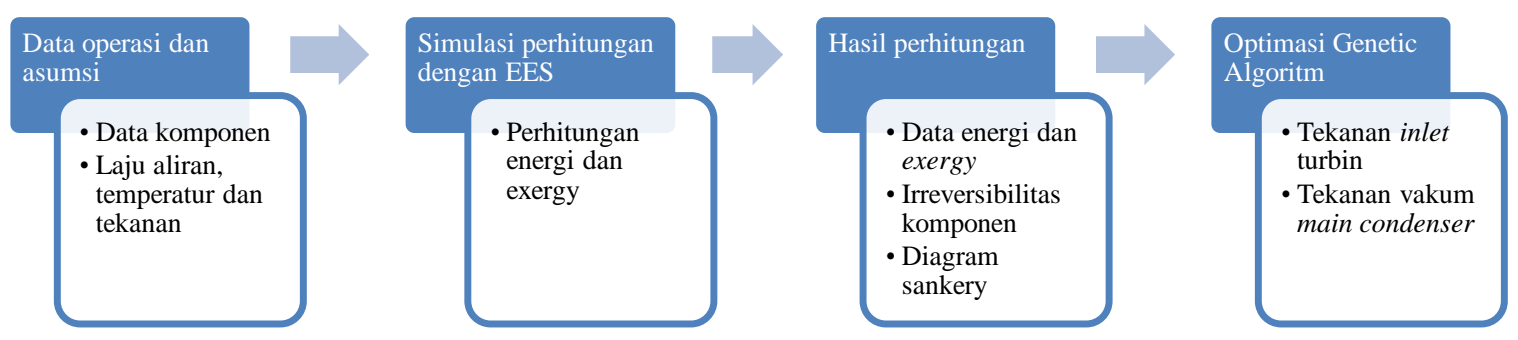

Gambar 2. Alur penelitian

\section{Pemodelan Skema Sistem}

Pemodelan sistem PLTP Kamojang ditunjukkan pada Gambar 3. serta parameter penelitan ini meliputi laju aliran massa $(\dot{\mathrm{m}})$, tekanan $(\mathrm{P})$, dan temperatur $(\mathrm{T})$ pada tiap state yang didapatkan pada data log sheet operasi dan produksi PLTP Kamojang Unit 3.

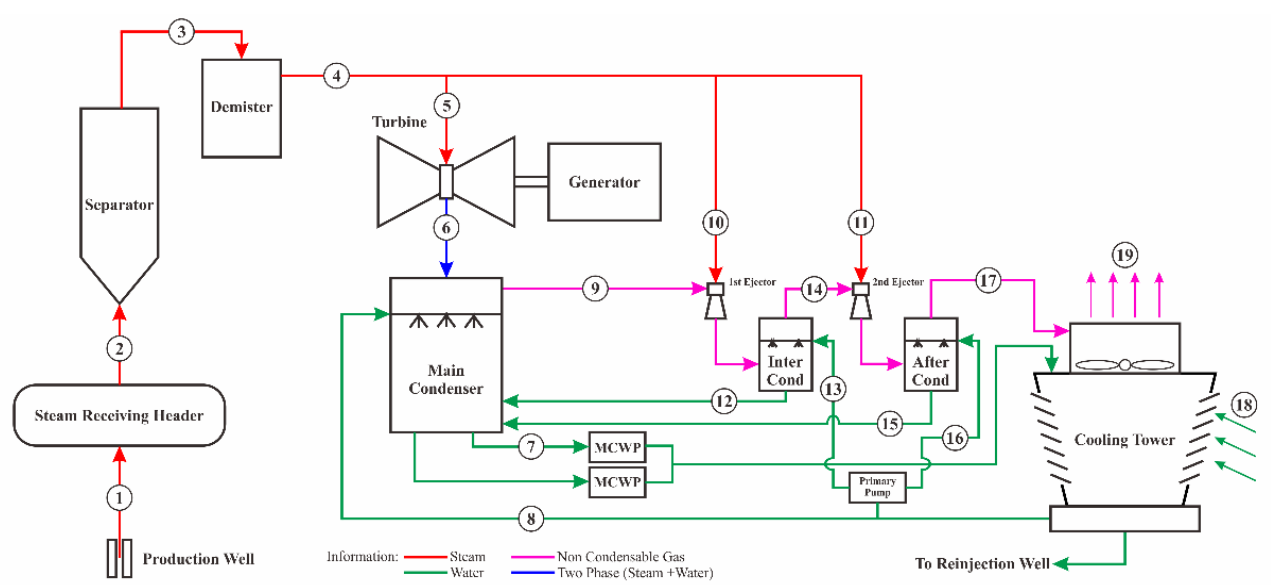

Gambar 3. Skema PLTP Kamojang

\section{Analisis Energi}

Analisis energi bertujuan untuk mengetahui nilai termal sistem berdasarkan sifat-sifat termodinamika pada masing-masing state yang didasarkan pada hukum termodinamika pertama. Pada analisis ini semua proses diasumsikan dalam keadaan tunak (steady state steady flow). Formulasi umum untuk melakukan analisis energi tiap state dan analisis energi tiap komponen seperti pada persamaan (1) dan (2) (Cengel and Boles, 2015).

$$
\begin{aligned}
& \dot{E} n_{\text {state }}=\dot{m} \cdot h_{\text {state }} \\
& \dot{E} n_{k}=\dot{m} \cdot\left(h_{i}-h_{0}\right)
\end{aligned}
$$

Berdasar pada hukum termodinamika pertama, panas yang masuk ke sistem, harus sama dengan kerja yang dihasilkan oleh sistem dalam bentuk daya atau mekanik. Sehingga dapat ditentukan:

$$
Q_{i}-Q_{0}=\dot{W}_{\text {output }}
$$

Selanjutnya, efisiensi termal pada pembangkit, khususnya Pembangkit Listrik Tenaga Panas Bumi (PLTP) dapat ditentukan dengan persamaan berikut: 


$$
\eta_{\text {thermal }}=\frac{\dot{W}_{\text {output }}}{Q_{\text {in }}} \times 100 \%
$$

\section{Analisis Exergy}

Exergy merupakan ukuran ketersediaan energi (available energy) atau energi yang dapat dimanfaatkan untuk melakukan kerja teoritis maksimum yang dapat diperoleh hingga sistem mencapai kesetimbangan dengan lingkungannya (dead state) (Moran and Saphiro, 2004).

Exergy total $(E)$ dalam suatu sistem dapat dibagi menjadi empat jenis yaitu exergy fisik $\left(E^{P H}\right)$, exergy kinetik $\left(E^{K N}\right)$, exergy potensial $\left(E^{P T}\right)$, dan exergy kimia $\left(E^{C H}\right)$ asalkan tidak adanya efek-efek nuklir, magnetik, elektrikal dan tegangan permukaan (Bejan et al, 1996). Sehingga laju exergy total pada sebuah sistem dapat diformulasilkan seperti pada persamaan (5).

$$
\dot{E}=\dot{E}^{P H}+\dot{E}^{K N}+\dot{E}^{P T}+\dot{E}^{C H}
$$

Exergy fisik selalu berkaitan dengan temperatur, entalpi dan entropi dari bahan atau komponen. Dalam sistem tertutup, laju exergy pada state tertentu dinyatakan seperti pada persamaan 2.21 (Bejan et al, 1996).

$$
\dot{E}=\dot{m} \cdot\left(\left(h-h_{0}\right)-T_{0}\left(s-s_{0}\right)\right)
$$

Pemusnahan exergy (exergy destruction) merupakan potensi kerja yang terbuang selama proses yang disebabkan karena ketidakmampuan balik atau ireversibilitas (Cengel and Boles, 2015). Exergy destruction biasanya disebut juga ireversibilitas. Besarnya nilai ireversibilitas pada tiap komponen dapat ditentukan menggunakan persamaan berikut:

$$
\dot{I}=\Sigma \dot{E}_{\text {in }}-\Sigma \dot{E}_{\text {out }}
$$

Efisiensi exergy dapat mengukur efisiensi pemakaian sumber daya dengan menggunakan exergy. Efisiensi exergy dapat memberikan sebuah ukuran sebenarnya dari kinerja sebuah sistem energi dari sudut pandang termodinamika (Bejan et al, 1996). Persamaan umum untuk menetukan efisiensi exergy pada komponen menggunakan persamaan berikut:

$$
\eta_{\text {exergy }, k}=\frac{\sum \dot{E}_{\text {out }}}{\sum \dot{E}_{\text {in }}} x 100 \%
$$

Sedangkan untuk menentukan efisiensi exergy sistem menggunakan persamaan berikut:

$$
\eta_{\text {sistem }}=\frac{\dot{W}_{\text {out }}}{\dot{E}_{\text {in }}} \times 100 \%
$$




\section{Optimasi Tekanan Vakum Main Condenser}

Optimasi dilakukan untuk menentukan nilai efisiensi exergy dan daya output yang maksimal. Variabel yang dioptimasi adalah tekanan vakum main condenser. Rentang nilai variabel akan ditentukan berdasarkan kondisi operasi pada pembangkit.

Tekanan vakum main condenser dianggap sama dengan tekanan keluaran turbin. Dalam heat balance dan data desain PLTP Kamojang, tekanan paling rendah dalam main condenser adalah 0,1 bar. Maka dalam analisa optimasi tekanan vakum main condenser akan divariasikan tekanan vakumnya sebesar 0,1 bar; 0,11 bar; 0,12 bar; 0,13 bar; dan 0,14 bar. Dari variasi tekanan vakum main condenser tersebut akan terlihat tekanan vakum yang optimal untuk menghasilkan efisiensi exergy paling tinggi. Peningkatan efisiensi eksergetik juga akan mempengaruhi daya keluaran sistem PLTP yang juga akan meingkat.

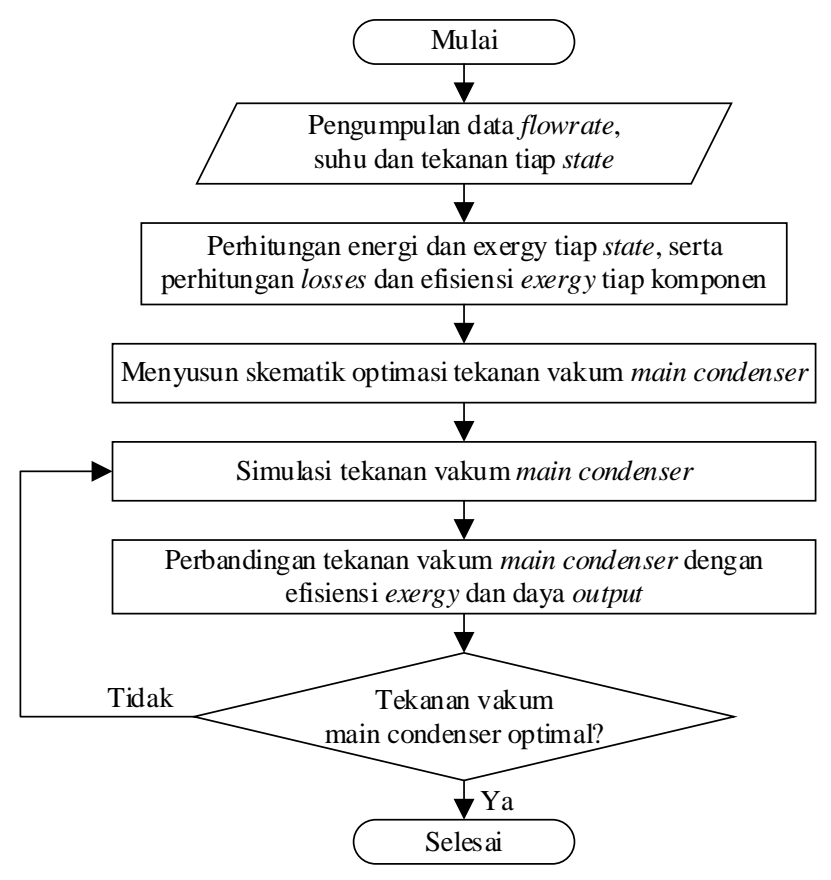

Gambar 4. Diagram alir penelitian

\section{HASIL DAN PEMBAHASAN}

\section{Analisis Energi}

Analis energi dilakukan untuk mengetahui kinerja sistem secara kuantitatif yang dapat diukur melalui pendekatan Hukum Termodinamika pertama tentang kekekalan energi. Diperoleh nilai laju energi pada tiap komponen yang ditunjukkan pada Tabel 3. 
Tabel 1. Laju Energi Tiap Komponen

\begin{tabular}{cc}
\hline Komponen & Laju Energi $\mathbf{( k W )}$ \\
\hline Steam Receiving Header & 326018 \\
Separator & 325864 \\
Demister & 325705 \\
Turbin & 315438 \\
Main Condenser & 718514 \\
Inter Condenser & 10879,5 \\
After Condenser & 9922 \\
Cooling Tower & 999203 \\
\hline
\end{tabular}

Berdasarkan Tabel 3 dapat diketahui nilai laju energi yang masuk pada tiap komponen. Laju energi dalam SRH sebesar $326018 \mathrm{~kW}$, laju energi separator $325864 \mathrm{~kW}$, dan laju energi demister sebesar $325705 \mathrm{~kW}$. Penurunan energi pada separator menuju demister karena adanya penurunan tekanan akibat proses pemisahan dalam separator. Proses pada steam receiving header, separator dan demister terjadi secara konstan tanpa adanya penambahan kerja dari luar sistem.

Turbin memiliki laju energi sebesar $315438 \mathrm{~kW}$, energi ini digunakan untuk memutar turbin dan generator untuk menghasilkan listrik. Berdasarkan perhitungan didapatkan nilai kerja turbin aktual sebesar $53416 \mathrm{~kW}$ dan kerja isentropis turbin sebesar $67096 \mathrm{~kW}$ dengan nilai efisiensi sebesar $79,61 \%$. Setelah uap melewati turbin, selanjutnya masuk ke main condenser yang memiliki nilai energi masuk sebesar $718514 \mathrm{~kW}$, energi ini berasal dari uap bekas turbin yang dikondensasi dengan air pendingin dari cooling tower. Laju energi pada inter dan after condenser masing-masing sebesar 10879,5 kW dan $9922 \mathrm{~kW}$, seerta komponen yang terakhir adalah cooling tower dengan nilai laju energi sebesar $999203 \mathrm{~kW}$.

\section{Analisis Exergy}

Untuk menghitung nilai exergy pada tiap komponen, maka perlu dihitung nilai exergy tiap state yang disajikan pada Tabel 4 berikut.

Tabel 2. Analisis Exergy tiap State

\begin{tabular}{lllllllll}
\multirow{2}{*}{ State } & Stream & & $\dot{\mathrm{m}}$ & $\mathrm{P}$ & $\mathrm{T}$ & Entalpi & Entropi & Exergy \\
\cline { 2 - 8 } & from & to & $\mathrm{kg} / \mathrm{s}$ & $\mathrm{bar}$ & ${ }^{\circ} \mathrm{C}$ & $\mathrm{kJ} / \mathrm{kg}$ & $\mathrm{kJ} / \mathrm{kg} . \mathrm{K}$ & $\mathrm{kW}$ \\
\hline 0 & Environment & & 0,813 & 18 & 75,54 & 0,2675 & \\
1 & Production well & SRH & 118,06 & 6,7 & 167 & 2554 & 6,248 & 95327 \\
2 & SRH & Separator & 118,06 & 6,5 & 167 & 2760 & 6,733 & 94821 \\
3 & Separator & Demister & 118,06 & 6,3 & 167 & 2759 & 6,744 & 94299 \\
4 & Demister & Turbine \& Ejector & 118,06 & 5,7 & 167 & 2754 & 6,777 & 92623 \\
5 & Demister & Turbine & 114,52 & 5,7 & 167 & 2754 & 6,777 & 89846 \\
6 & Turbine & Main Condenser & 114,52 & 0,12 & 51,3 & 2288 & 7,148 & 24090 \\
7 & Main Condenser & Cooling Tower & 3512,44 & 2,94 & 48,4 & 202,6 & 0,683 & 21783 \\
8 & Cooling Tower & Main Condenser & 3311,11 & 0,813 & 31,6 & 132,4 & 0,4585 & 4108 \\
9 & Main Condenser & $1^{\text {st }}$ Stage Ejector & 0,22 & 0,41 & 33 & 2343 & 6,82 & 79,42 \\
10 & Demister & $1^{\text {st }}$ Stage Ejector & 1,76 & 5,7 & 167 & 2754 & 6,777 & 1381 \\
11 & Demister & $2^{\text {nd }}$ Stage Ejector & 1,54 & 5,7 & 167 & 2754 & 6,777 & 1208
\end{tabular}




\begin{tabular}{lllllllll}
12 & Inter Condenser & Main Condenser & 43,59 & 0,813 & 50 & 209,3 & 0,7037 & 298,7 \\
13 & Primary Pump & Inter Condenser & 41,67 & 3,05 & 31,6 & 132,4 & 0,4585 & 51,7 \\
14 & Inter Condenser & $2^{\text {nd }}$ Stage Ejector & 0,07 & 0,41 & 59,9 & 2343 & 6,82 & 25,27 \\
15 & After Condenser & Main Condenser & 43,44 & 0,81 & 50 & 209,3 & 0,7037 & 297,7 \\
16 & Primary Pump & After Condenser & 41,67 & 3,05 & 31,6 & 132,4 & 0,4585 & 51,7 \\
17 & After Condenser & Fan Stack CT & 0,05 & 0,813 & 42,6 & 2666 & 7,428 & 25,33 \\
18 & Environment & Cooling Tower & 3891 & 0,813 & 17,6 & 73,87 & 0,2618 & 0 \\
19 & Cooling Tower & Environment & 3891 & 0,813 & 34,4 & 144,1 & 0,4968 & 7736 \\
\hline
\end{tabular}

Analisis exergy dilakukan untuk mengetahui besar, letak dan penyebab terjadinya irreversibilitas atau exergy losses pada komponen utama PLTP Kamojang. Pada penelitian ini hanya memperhitungan exergy physic karena pada sistem tidak terjadi proses perubahan kimia, potensial dan kinetik. Hasil perhitungan yang telah dilakukan diperoleh jumlah exergy masuk, exergy keluar serta irreversibilitas pada tiap komponen seperti pada Tabel 5 berikut.

Tabel 3. Laju exergy masuk, exergy keluar dan irreversibilitas dan efisiensi exergy

\begin{tabular}{lllll}
\hline Komponen & $\begin{array}{l}\text { Exergy masuk } \\
(\mathbf{k W})\end{array}$ & $\begin{array}{l}\text { Exergy keluar } \\
(\mathbf{k W})\end{array}$ & $\begin{array}{l}\text { Irreversibilitas } \\
(\mathbf{k W})\end{array}$ & $\begin{array}{l}\text { Efisiensi } \\
\text { Exergy }(\%)\end{array}$ \\
\hline Steam Receiving Header & 95327 & 94821 & 506 & 99,47 \\
Separator & 94821 & 94299 & 522 & 99,45 \\
Demister & 94299 & 92623 & 1676 & 98,22 \\
Turbin & 89846 & 76972 & 12874 & 85,67 \\
Main Condenser & 28794,4 & 21862,42 & 6931,98 & 75,93 \\
Inter Condenser & 1512,12 & 323,97 & 1188,15 & 21,42 \\
After Condenser & 1284,97 & 323,03 & 961,94 & 25,14 \\
Cooling Tower & 21783 & 11844 & 9939 & 54,37 \\
\hline
\end{tabular}

Berdasarkan Tabel 3 di atas, exergy masuk ke steam receiving header dari sumur produksi sebesar $95327 \mathrm{~kW}$ dan exergy keluar sebesar $94821 \mathrm{~kW}$ dengan nilai irreversibilitas sebesar $506 \mathrm{~kW}$ dan efisiensi sebesar 99,47\%. Pada separator terdapat exergy masuk sebesar $94821 \mathrm{~kW}$ dan exergy keluar sebesar $94299 \mathrm{~kW}$ dan efisiensi sebesar 99,45\%. Irreversibilitas pada separator terjadi karena prinisp pemisahan menggunakan gaya sentifugal atau cyclone separation, yang mana uap masuk separator dikondisikan agar menciptakan gaya sentrifugal untuk menciptakan vortex.

Demister memiliki 94299 kW pada exergy masuk dan 92623 pada exergy keluar. Uap pada demister sebagian kecil digunakan sebagai auxiliary steam pada gas removal system sehingga efisiensi demister sebesar 98,22\%. Sedangkan pada turbin nilai exergy masuk dan keluarnya sebesar $89846 \mathrm{~kW}$ dan $76972 \mathrm{~kW}$ dimana yang dikonversi menjadi energi listrik sebesar $52882 \mathrm{~kW}$ sehingga nilai irreversibilitasnya sebesar $12874 \mathrm{~kW}$. Irreversibilitas disebabkan proses ekspansi selama uap melewati blade turbin. Silika yang terikut dalam uap juga berpengaruh terhadap adanya irreversibilitas turbin yang menyebabkan turunnya 
performa turbin dan berdampak terhadap turunnya kemampuan pembangkit untuk memproduksi listrik.

Condenser terbagi menjadi tiga komponen yaitu main condenser, inter condenser dan main condenser. Efisiensi exergy pada komponen tersebut masing-masing 75,93\%, 21,42\% dan $25,14 \%$, nilai efisiensi pada inter dan after condenser merupakan dua nilai terendah dari semua komponen. Nilai exergy masuk ke main condenser sebesar $28794,4 \mathrm{~kW}$ dan exergy keluar sebesar 21862,42 kW, irreversibilitas dipengaruhi oleh exhaust steam heat rejection yaitu proses hilangnya panas akibat ekspansi dalam turbin. Serta nilai exergy masuk ke cooling tower sebesar $21783 \mathrm{~kW}$ dengan nilai efisiensi exergy sebesar 55,37\%.

Selain efisiensi exergy tiap komponen, juga dapat diketahui efisiensi exergy keseluruhan sistem PLTP dengan membandingkan exergy produk dalam hal ini adalah daya yang dibangkitkan dengan exergy masuk ke sistem yang berasal dari sumur produksi. Hasil dari perhitungan dapat diketahui bahwa efisiensi exergy keseluruhan sistem sebesar 55,47\%.

Gambaran mengenai besarnya nilai efisiensi exergy pada tiap komponen ditunjukkan dalam Diagram Sankey pada Gambar 5 berikut.

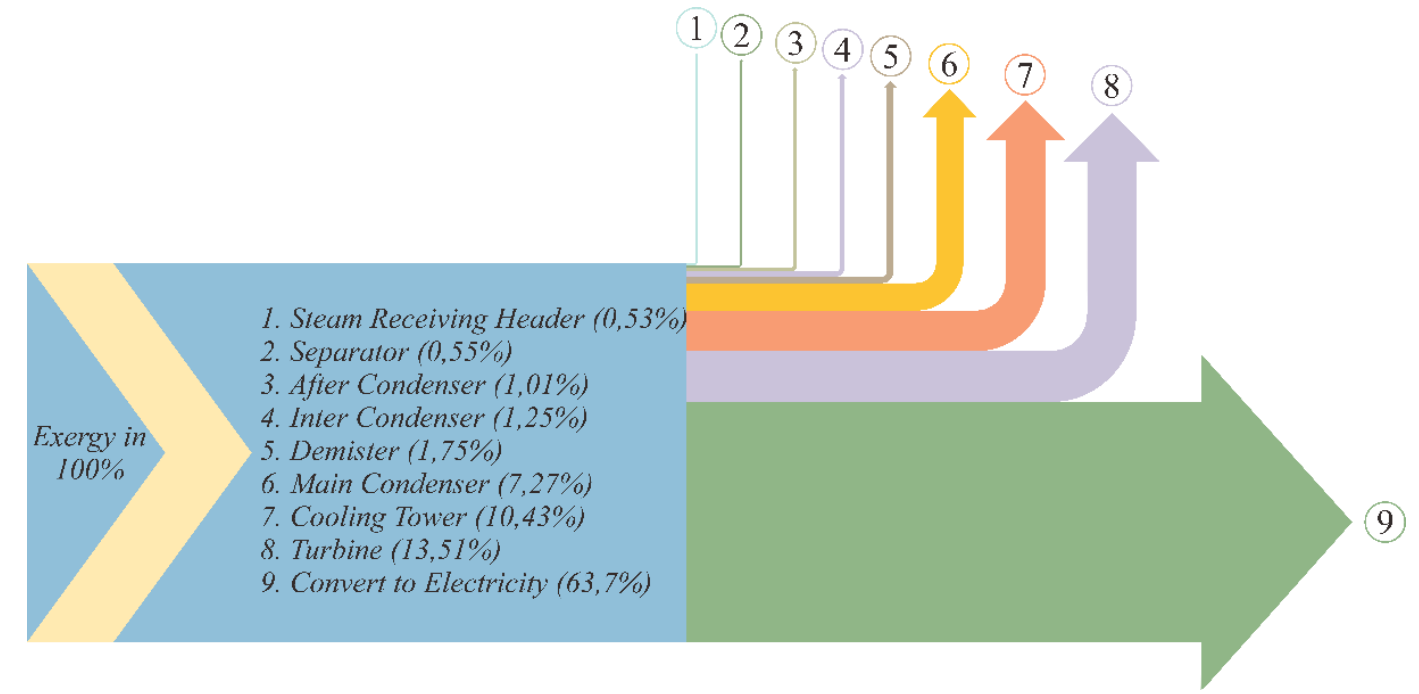

Gambar 5. Diagram sankey aliran exergy PLTP Kamojang

Dengan diagram Sankey digunakan untuk memberikan gambaran yang lebih jelas tentang aliran exergy pada PLTP Kamojang. Total laju exergy yang masuk ke sistem sebesar $95327 \mathrm{~kW}$, akan tetapi laju exergy tersebut tidak semuanya bisa dikonversi menjadi listrik karena adanya exergy destruction sebagai akibat dari irreversibilitas komponen pada sistem PLTP. Gambar 4 menunjukkan besarnya exergy hilang pada steam receiving header sebesar $0,53 \%$ atau $506 \mathrm{~kW}$, separator sebesar $0,55 \%$ atau $522 \mathrm{~kW}$, demister sebesar $1,76 \%$ atau $1676 \mathrm{~kW}$, turbin sebesar $13,51 \%$ atau $12874 \mathrm{~kW}$, main condenser sebesar 7,27\% atau 
$6931,98 \mathrm{~kW}$, inter condenser sebesar $1,25 \%$ atau $1188,15 \mathrm{~kW}$, after condenser sebesar $1,01 \%$ atau $961,94 \mathrm{~kW}$ dan cooling tower sebesar 10,43\% atau $9939 \mathrm{~kW}$. Total exergy yang bisa dikonversi menjadi listrik sebesar $63,7 \%$ atau $60727,93 \mathrm{~kW}$.

\section{Optimasi Tekanan Vakum Main Condenser}

Hasil perhitungan dan simulasi pengaruh tekanan vakum pada main condenser terhadap efisiensi exergy sistem dan irreversibilitas ditampilkan dalam Gambar 6 berikut.

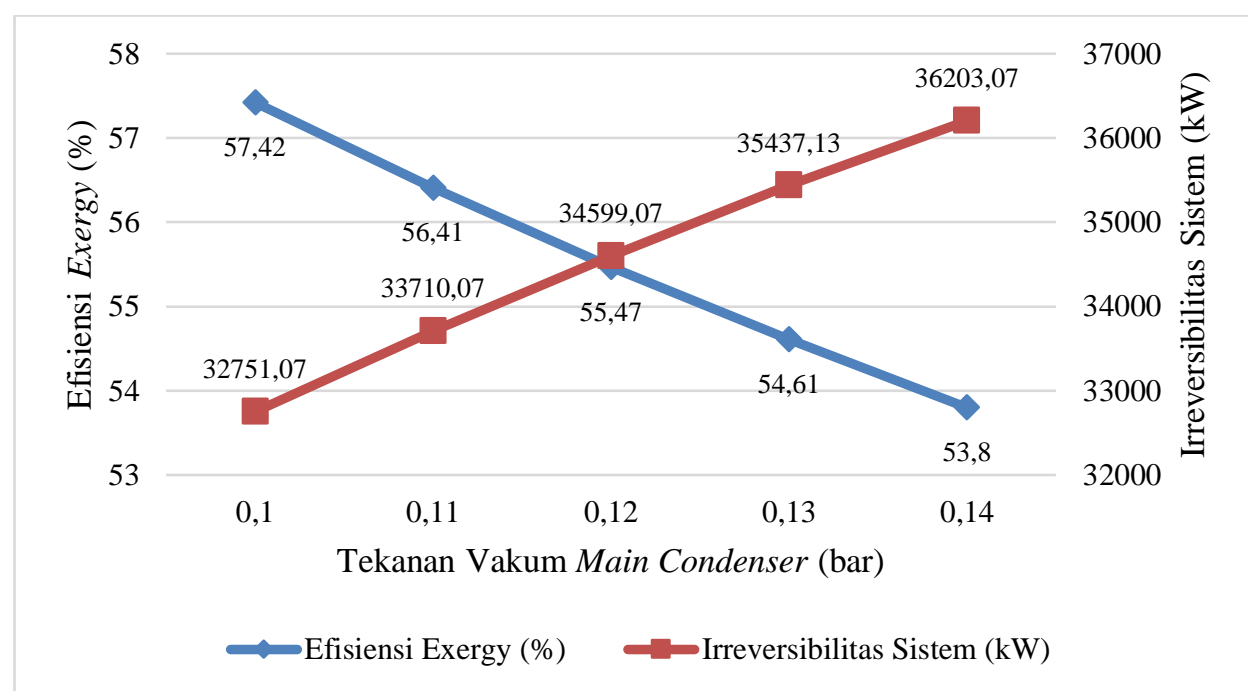

Gambar 6. Grafik Pengaruh Tekanan Main Condenser terhadap Efisiensi Exergy dan Irreversibilitas

Dari Gambar 4.5 dapat diketahui bahwa efisiensi exergy sistem pada tekanan vakum main condenser 0,1 bar sebesar 57,42\%, 0,11 bar sebesar 56,41\%, 0,12 bar sebesar 55,47\%, 0,13 bar sebesar 54,61\% dan 0,14 bar sebesar 53,8\%. Hasil ini menunjukkan bahwa efisiensi exergy sistem menurun seiring dengan semakin besarnya nilai tekanan dalam main condenser.

Sedangkan irreversibilitas sistem pada tekanan 0,1 bar sebesar $32751,07 \mathrm{~kW} ; 0,11$ bar sebesar 33710,07 kW; 0,12 bar 34599,07 kW; 0,13 bar 35437,13 kW; dan 0,14 bar 36203,07 kW. Hasil ini menunjukkan bahwa semakin tinggi tekanan dalam main condenser menyebabkan irreversibilitas sistem meningkat. Hal ini berbanding terbalik dengan nilai efisiensi exergy sistem. Dalam penjelasan sebelumnya menunjukkan bahwa semakin tinggi tekanan dalam main condenser akan meningkatkan nilai efisiensi exergy sistem.

Parameter lain yang dipengaruhi oleh tekanan vakum pada main condenser yaitu pada daya output pembangkit. Dimana efisiensi exergy pada pembangkit sangat dipengaruhi oleh daya output pembangkit itu sendiri. Berikut akan disajikan data hasil perhitungan dan 
simulasi mengenai pengaruh tekanan vakum pada main condenser terhadap daya output pada PLTP Kamojang pada Gambar 7 berikut

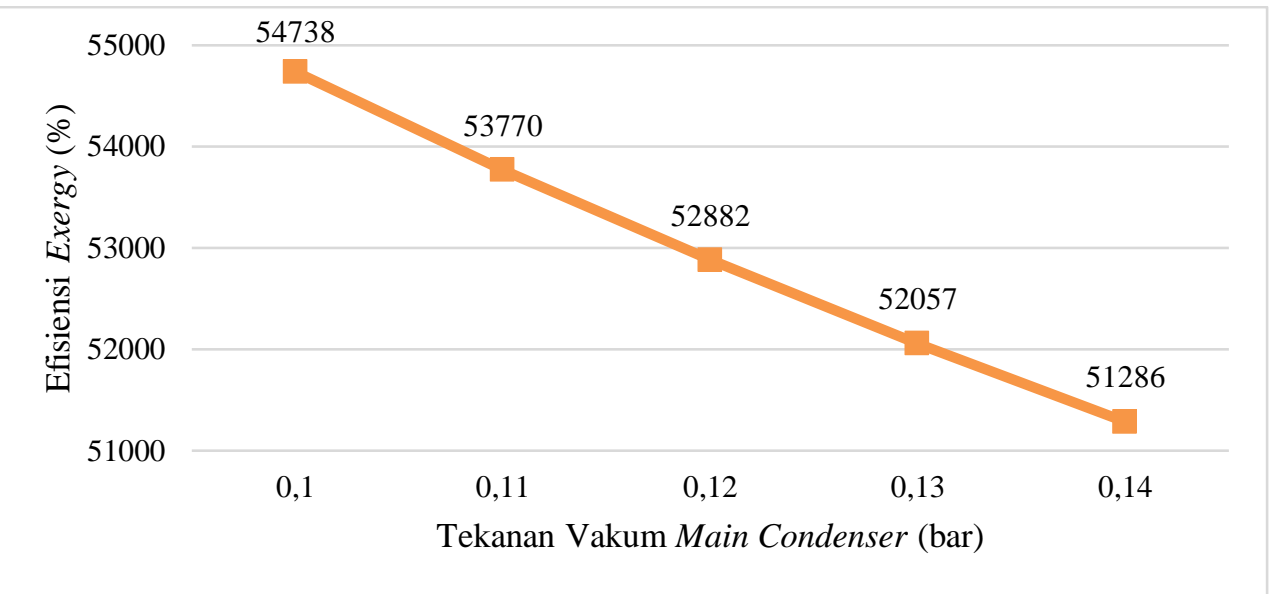

Gambar 7. Grafik Pengaruh Tekanan Vakum Main Condenser terhadap Daya Output

Dari Gambar 4.7 dapat diketahui bahwa daya output pembangkit berdasarkan pengaruh tekanan vakum pada main condenser, pada tekanan vakum 0,1 bar, daya terbangkit sebesar $54738 \mathrm{k} \mathrm{kW}, 0,11$ bar sebesar $53770 \mathrm{~kW}, 0,12$ bar sebesar $52882 \mathrm{~kW}, 0,13$ bar sebesar 52057 $\mathrm{kW}$ dan pada 0,14 bar sebesar $51286 \mathrm{~kW}$. Hal ini menunjukkan bahwa semakin besar tekanan dalam main condenser maka daya terbangkit juga akan menurun. Hal ini sebanding dengan nilai efisiensi exergy sistem yang juga semakin menurun, karena efisiensi exergy sistem bergantung pada daya output yang dibangkitkan oleh PLTP.

\section{KESIMPULAN}

Analisis exergy menunjukkan adanya exergy masuk ke sistem dari sumur produksi sebesar $95327 \mathrm{~kW}$, nilai efisiensi exergy sistem sebesar 55,47\%, dan daya output pembangkit sebesar $52882 \mathrm{~kW}$. Main condenser merupakan komponen yang sangat penting dalam pembangkit listrik tenaga panas bumi untuk menjaga kinerja turbin tetap optimal. Optimasi dilakukan pada tekanan vakum main condenser dengan perhitungan dan simulasi menggunakan software EES. Hasil optimasi menunjukkan bahwa nilai tekanan vakum main condenser paling optimal sebesar 0,1 bar dengan menghasilkan efisiensi exergy tertinggi 57,42\% dan daya output tertinggi $54738 \mathrm{~kW}$ dan irreversibilitas terendah sebesar 32751,07 kW.

\section{DAFTAR PUSTAKA}

Adiprana, R., D. S. Purnomo., and I. E. Lubis. (2015). Kamojang Geothermal Power Plant Unit 1-2-3 Evaluation and Optimization Based on Exergy Analysis. in Proceedings World Geothermal Congress. Melbourne, Australia, 19-25 April 2015. 
Bejan, A., G. Tsatsaronis, M. Moran. (1996). Thermal Design and Optimization. New York: John Wiley and Sons Inc.

Cengel, Y. A. and M. A. Boles. (2015). Thermodynamic an Engineering Approach. 8th Ed. New York: McGraw-Hill Education.

Darma, S., Tisnaldi, and G. Rony. (2010). Country Update: Geothermal Energy Use and Development in Indonesia. dalam Proceedings World Geothermal Congress 2010. Bali Indonesia.

Dastanpour, A., R. A. R., Mahmood. (2013). Feature Selection Based on Genetic Algorithm and Support Vector Machine for Intrusion Detection System. dalam SDIWC International Conferences 2013. hal 169-181.

Dewan Energi Nasional. (2019). Outlook Energi Indonesia (Indonesia Energy Outlook). Jakarta: Sekretariat Jenderal Dewan Energi Nasional.

Dincer, I., and M.A. Rosen. (2012). Exergy, Energy, Environment and Sustainable Development. United State of America's Elsevier Science.

Moran M. J., H. N. Shapiro, D. D. Boettner, M. B. Bailey. (2014). Fundamental of Engineering Themodynamics Eight Edition. New York: John Wiley and Sons Inc.

Rudiyanto, B., I.A. Illah, N.A. Pambudi, C. Ceng. R. Adiprana, M. Imran, L.H. Saw, and R. Handogo. 2017. Preliminary Analysis of Dry-Steam Geothermal Power Plant by Employing Exergy Assessment Case Study in Kamojang Geothermal Power Plant, Indonesia. In Journal of Case Studies in Thermal Engineering, 10. P. 292-301. 